\title{
El Niño forecast fails to convince sceptics
}

[LONDON] Predictions that the expected El Niño - the appearance of warm waters off the coast of South America, bringing droughts, storms and floods in its wake will be stronger than usual are facing scepticism from the countries that could be most strongly affected.

In particular, scientists from Argentina and Peru say they are not yet convinced by reports from the US National Oceanic and Atmospheric Administration (NOAA) that El Niño, which usually occurs in winter every two to seven years, could arrive early, and be the strongest for 25 years.

The forecast, issued on 26 June, says that Indonesia and India are expected to be drier than normal (see panel), while central Chile, Uruguay, southern Brazil, Peru and central Argentina are likely to experience a wetter than normal winter.

But Pablo Lagos, scientific director at the Geophysical Institute of Peru in Lima, is unconvinced. He says it is far too early to take drastic steps, such as changing agriculture patterns, in response to the NOAA prediction. "What is the point of spending so much money if the prediction turns out to be wrong?" he says. "It is better to wait and act only when we are sure."

Hugo Hordij, director of the Climatic Analysis Centre of Argentina's National Meteorological Service, agrees, adding that

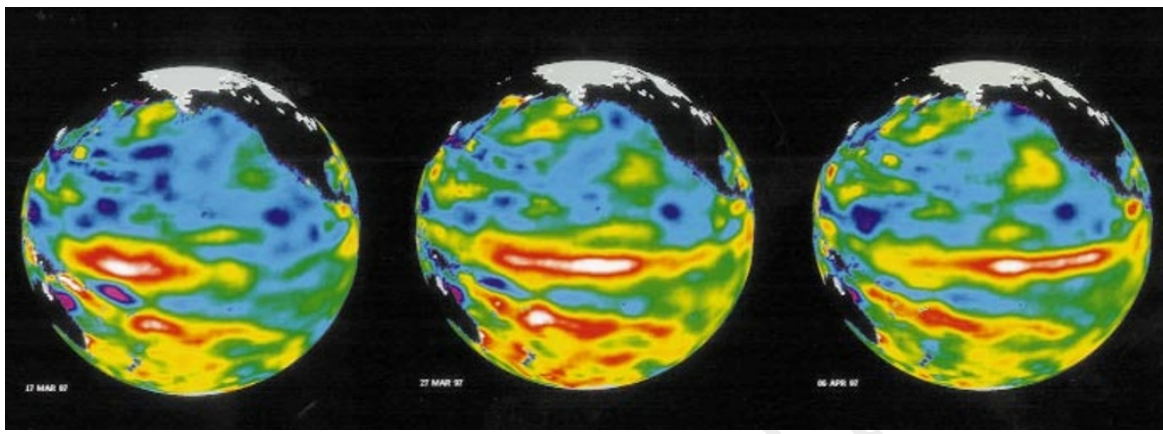

These images of sea-surface height relative to normal ocean conditions are evidence of an imminent 'bad' El Niño. A warm water oscillation (white/red) is shown in the equatorial Pacific during March and April this year. The data were collected by the joint US/French TOPEX/Poseidon satellite.

he doubts Argentina will be affected by El Niño to the extent predicted by NOAA.

The NOAA prediction was based partly on the abnormally high sea-surface temperatures that have been recorded in parts of the East Pacific, and along and near the west coast of South America. These temperatures continued to increase throughout June, and are now around $2-3^{\circ} \mathrm{C}$ higher than average.

Such conditions are similar to those observed in 1957 and 1972, both years in which an El Niño event led to droughts near the eastern end of the Pacific Ocean and caused increased rain leading to floods at the western end of the Pacific.

Michael Glantz, a senior scientist at the

\section{Indian monsoon 'progressing normally'}

[NEW DELHI] The Indian

Meteorological Department

has expressed doubts about whether the predicted return of a strong El Niño this year will cause drought in some parts of India and affect the seasonal monsoons.

"The southwest Indian monsoon arrived a week late but, contrary to fears, it has so far been progressing normally and has already covered most of the country," says R. R. Kelkar, a senior official of the department.

Kelkar was reacting to statements by Ants Leetmaa, director of the Climate Prediction Center of the US National Oceanic and Atmospheric Administration, that the 'big' El Niño predicted this year for the equatorial Pacific is likely to bring drought to India, South Africa, Australia and parts of Brazil (see above).
According to Indian scientists, India's monsoon is "a gigantic complex phenomenon" in which El Niño is just one of several contributory factors. In the monsoon season, which runs from June to September, about $80 \mathrm{~cm}$ of rain falls throughout India. The department believes that India will get around 92 per cent of that amount this year, which is considered satisfactory.

This prediction is based on an empirical 16-parameter model that the department has been using successfully since 1988 (see Nature 342, 4; 1989). Kelkar says that the El Niño phenomenon has been incorporated into calculations for this year's forecast.

After analysing monsoon rainfall data between 1951 and 1990, Indian meteorologists say that there is no clear correlation between El Niño and the Indian monsoon. "There have been many years in the past when monsoon rainfall was in excess or normal in El Niño years, and there were years when rainfall was deficient when there was no El Niño," says Kelkar. Indeed, India had a normal monsoon in 1983 when Peru witnessed its worst El Niño since 1950.

India's monsoons over the past nine years have proved unexceptional, and the US warning has come as something of a surprise to the government. Although the meteorological department claims that it has allayed fears, the agriculture ministry is preparing to install pumps and borewells for irrigating crops, in case the rains fail.

K.S. Jayaraman
National Center for Atmospheric Research at Boulder, Colorado, and author of Currents of Change: El Niño's Impact on Climate and Society, believes that the advice given to the governments of Peru and Argentina by their scientists is prudent. "You can't take these predictions at face value," he says.

"There is no one-to-one correlation between high sea-surface temperatures and an El Niño," says Glantz. For example, he says, the 1991-92 El Niño was preceded by variable temperatures off the coast of Peru which fluctuated considerably above and below their average values.

Lagos, meanwhile, says that Peru is not wholly disregarding the latest forecast, merely waiting for more precise data. Peru, he says, has a comprehensive two-stage action plan in place, should an El Niño strike. The plan is based in part on the lessons that the country learned in 1982-83, when a lack of preparation for what turned out to be the strongest El Niño since 1950 led to 600 deaths as a result of severe flooding, and US\$900 million worth of damage.

The first phase, which Lagos says has already been set in motion, consists of campaigns to make the public aware of the possibility and the possible impact of an El Niño. The second phase starts "once we are more sure about an El Niño”, Lagos adds.

This phase includes drilling into underground water aquifers to ensure clean water supplies, and encouraging the textile industry to ensure that stocks of warm clothing are protected from floods. A law is being considered banning anchovy fishing to conserve depleted fish stocks, which migrate during an El Niño. Farmers, meanwhile, may be encouraged to grow crops that would benefit from a wetter climate.

An El Niño, however, is not all bad news for Peruvian farmers. Some take advantage of the prospect of torrential rainfall by planting copious quantities of seed in desert areas, in the hope of cultivating pastures for their cattle. "Many farmers have already started doing this," says Lagos. 